\title{
Total War Strategy with Passive Radar Operation
}

\author{
Imam Taufik, Lukman Yudho Prakoso, Helda Risman \\ Universitas Pertahanan, Indonesia
}

\begin{abstract}
Indonesia as an archipelagic state has an open sea area and the existence of the Indonesian Archipelago Sea Channel (ALKI) which creates vulnerabilities to various possible threats. Balitbang Kemhan RI has developed a passive radar detection tool that can be used for sensing all activities deemed necessary in national defense, especially for preparation in case of universal war. This paper will analyze the implementation of the existing early detection system using the theory of Lukman Yudho Prakoso (2016) which states that public policy in the defense sector can be achieved well if Integrative, Interactive, Transparency, Controling and Accountability (IITCA) factors are respected. The writing method used is descriptive qualitative literature study. The next writer will formulate a strategy so that the total war strategy can be optimal by operating an early detection system using passive radar. The results showed that the IITCA factor had not been fulfilled in the implementation of the existing early detection system operation defense policy, so that the formulation of a universal war strategy with passive radar operation that would later be implemented had to be integrated, interactive, transparent, had a control system and had to be accountable. As a conclusion, the universal war strategy with the operation of passive radar made by the Indonesian Ministry of Defense Balitbang, is very effective in achieving defense objectives in maintaining and protecting the sovereignty of the country, the territorial integrity of the Republic of Indonesia and the safety of the entire nation from all forms of threats.
\end{abstract}

Keywords: Strategy, Total War, Passive Radar

\section{INTRODUCTION}

$\mathrm{T}$ he development of defense technology has forced every country to modernize its military equipment. The modernization of the defense equipment includes increasing the capability of missile technology, radar and fighter aircraft as well as the codal communication system. This also has an effect on increasing threats to the defense and security of a country. Western countries are developing combat aircraft capable of stealth, where the aircraft can escape from active enemy radar. Because these planes are made of materials that can absorb electromagnetic waves with radar cross sction which is so small that it cannot reflect electromagnetic waves. Meanwhile, the eastern bloc countries, especially Russia, China and their allies are developing radars that can detect stealth capable .

The development of the situation in the South China Sea, where China has unilaterally claimed that the entire South China Sea region is its territory. This has caused unrest among Southeast Asian countries bordering the South China Sea. China claims the South China Sea by implementing an area boundary called the dashed line that disturbs the Exclusive Economic Zone (EEZ) of Southeast Asian countries including Vietnam, the Philippines, Cambodia, Malaysia, Brunei
Darussalam and Indonesia. The South China Sea also contains offshore oil and gas natural resources as well as biological natural resources, namely fisheries. China's action also provoked the presence of the United States, which also has an interest in the South China Sea. The United States has an interest in the region because the South China Sea is connected to the Strait of Malacca, which is the world's crosssea trade route connecting the western and eastern world. Construction of artificial islands on atolls and patrolsThe Chinese Coast Guard has seriously disturbed fishermen from Southeast Asian countries, thus threatening the livelihoods of fishermen. This often results in conflicts between fishermen and Chinese patrol boats.

The election of President Joko Widodo in the 2014 and 2019 presidential elections together with his Nawacit program gave rise to the concept of Indonesia becoming a World Maritime Axis (PMD), due to the strategic location of Indonesia being at the crossroads of world traffic between two continents and two oceans. Massive infrastructure development is carried out in the transportation sector, both sea transportation and its marine toll road program, construction of toll roads in Sumatra, Java, Kalimantan, Sulawesi and trans Papua as well as the MRT line in the capital city of Jakarta, providing a lot of progress in various fields, especially the economy and foreign investment. In the field of Defense, the concept of universal people's defense has become the concept of state defense of the Republic of Indonesia. This concept has been included in the 2015 White Paper of Defense which is also a mandate of the 1945 Constitution.

Universal people's defense is a defense system that does not only involve the TNI as the main component, but also involves the reserve and supporting components. The reserve component consists of the people who have received state defense training and the supporting components are all existing resources, both natural and artificial. ${ }^{1}$ The concept of universal people's defense is expected to be able to overcome military and non-military threats. Based on the development of the strategic environment that has been described above, it is possible to create military threats from land, sea and air. Therefore, the TNI as the main component must have an accurate and precise detection tool, making it easier for the commanders and commanders to make decisions quickly and accurately.

\footnotetext{
${ }^{1}$ Buku Putih Pertahanan 2015, hlm 28-29
} 
Referring to the characteristics of Indonesia's territory which consists of thousands of islands surrounded by oceans, Indonesia needs military equipment that can detect air, sea and land threats early and in an integrated manner. Sea, land and air areas must always be monitored at all times, because threats do not recognize the time and place. The land border area is an area that is prone to territorial violations by foreign parties, because Indonesia has a fairly long territorial border as well, especially in the northern island of Kalimantan, which borders the state of Malaysia. On the island of Papua, land borders with the state of Papua New Guinea, and on the island of Timor land borders with the state of Timor Leste. Land border areas are prone to transnational crimes such as smuggling of weapons, drugs, smuggling of illegal goods and human trafficking. Land borders are also prone to shifting of border stakes between countries by neighboring countries which have recently occurred in North and West Kalimantan. Therefore, along the land border, it is necessary to have a detection tool that can monitor the border area. Ideally, each Kodam has a Puskodal room (Central Command Control) which allows a Pangdam or Operations Assistant to monitor security in land border areas from the monitor screen of the Military Region Command Control Center.

Most of Indonesia is an ocean. Where, as an archipelago, Indonesia has the longest coastline in the world. This means that Indonesia's maritime borders are very long and wide. So this is a challenge to Indonesia's maritime defense. Maritime defense must be able to secure 12 miles of territorial sea as well as the Exclusive Economic Zone (EEZ) 200 miles from the outer coast of Indonesian territory. Therefore we need an early detection tool that can monitor the security of the maritime border area. This detection tool should be integrated, because with the integration of this detection tool, it will make it easier for military leaders to make decisions quickly and accurately. Ideally, each Lantamal has a Puskodal system that can monitor Indonesian Navy ships, foreign ships and domestic ships passing through the sea border and ALKI (Indonesian Archipelago Sea Route).

The area of Indonesian air sovereignty is the widest area when faced with the tasks of the Air Force in accordance with Law Number 34 of 2004, namely maintaining Indonesia's national airspace sovereignty. Air superiority is something that absolutely must be controlled in order to maintain national airspace sovereignty. Security of national airspace is part of air defense operations which is the responsibility of the TNI Kotama, namely the National Air Defense Command (Kohanudnas). ${ }^{2}$ In carrying out its duties, Kohanudnas is divided into 4 National Air Defense Sector Commands (Kosekhanudnas). Kosekhanudnas I is headquartered at Halim Perdanakusuma Jakarta, Kosehanudnas II in Makassar, Kosekhnaudnas III in Medan and Kosehanudnas IV is headquartered in Biak, Papua. Each Kosekhanudnas is in charge of elements, namely elements of radar, free combat, air bases, point defense, passive defense, KRI with Hanud capability, as well as elements of MCC (Military Civil Coordination). The detection tool used by Kohanudnas is currently 21 active radars scattered throughout Indonesia. To maximize the observation of national airspace, it is necessary to have a passive radar integrated with active radar to cover several blank spot areas and monitor areas prone to violations of national airspace, especially to detect targets that are not able to be detected by active radar.

According to Billy Mitchell's Air Power theory, air superiority is absolutely necessary for a country if it wants to win future wars. Because according to Billy Mitchel, the war in the future of aerospace technology is increasingly developing, so that those who control air superiority will have a great chance of winning the battle. Where the victory of sea and land power is largely determined by the protection of "Air Power".

Maintaining the sovereignty of the territory of the Unitary State of the Republic of Indonesia which is so vast is the task of the TNI, this is stated in Law number 34 of 2004. Ground defense is the duty of the TNI AD, where the Army has 17 Kodam, Kotama Kostrad, Kopasus along with supporting elements such as Arhanud., armed and others. Currently, the TNI is using a detection tool in the form of an active radar to monitor potential threats. As mentioned above, Kohanudnas has the responsibility for securing national airspace. Kohanudnas currently operates 21 active radars consisting of 8 Thomson radars, 3 Plessey AR 325 Comannder radars, 5 Master T radars, 3 Plessey AWS II radars, and 2 Webel radars.

The number of Air Defense Radar (Hanud) belonging to the TNI is currently unable to cover all national airspace. Where many areas are still "blank spot areas". Where these areas are very likely to occur violations of land and sea airspace by foreign parties which can occur at any time. It is feared that foreign parties may exploit Indonesia's natural resources without being monitored by the state. This could disturb the territorial integrity of the Republic of Indonesia.

Based on government regulation No.37 of 2002 concerning the Indonesian Archipelago Sea Channel (ALKI), it is divided into 3 parts. ALKI I stretches from the South China Sea, Karimata Strait, to the Sunda Strait and ends in the Indian Ocean. ALKI II stretches from the Sulawesi Sea, Lombok Strait to the Indian Ocean. ALKI III stretches from North Maluku to Southeast Maluku. The Indonesian Archipelago Sea Channel can be seen in Figure 1. 


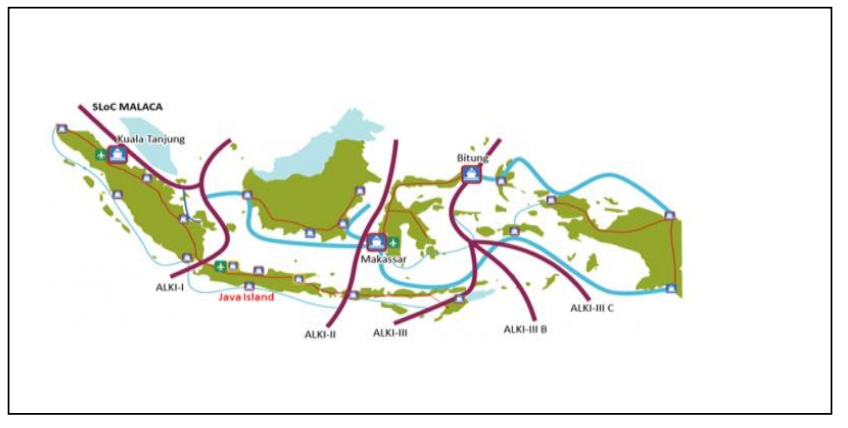

Fig1. ALKI

The ALKI route divides the Indonesian archipelago into 3 parts. It is on this route that many foreign ships have passed, including ships from countries that ratified the 1982 United Nations Convention on The Law of the Sea (UNCLOS). One of the countries that did not ratify UNCLOS 1982 was the United States. So that several years ago there was an incident on the island of Bawean, namely the maneuvering of US fighter aircraft over the island of Bawean without permission from the Indonesian government. These fighters flew under the pretext of escort procedures for US carriers. The incident resulted in disruption of domestic flight routes. Therefore, the ALKI route is an area that is prone to territorial violations by foreign parties.

Kohanudnas is the city of the TNI which has the task of carrying out air defense operations in Indonesia. Operationally, Kohanudnas is under the TNI Commander, but in terms of guidance, it is under Mabesau. Air surveillance is part of air defense operations. Kohanudnas conducts all-time aerial observation operations. In carrying out air observation tasks, the National Kohanudnas annually records the number of violations of national airspace, both committed by domestic and foreign aircraft. Violations that are carried out by domestic aircraft are usually committed by flying that is not in accordance with the route or other violations that are not in accordance with the provisions of the International Civil Aviation Organization (ICAO) and the Law of the Republic of Indonesia first number 1 of 2009 concerning aviation. Violations by foreign aircraft are usually carried out in relation to licensing issues and violations of airspace that enter Indonesian territorial areas more than 12 miles away.

Regarding the universal war strategy, the use of detection tools is an important element in the defense system. The use of active radar alone is not sufficient to monitor airspace, sea and land targets. Because the use of active radar alone still has weaknesses for today's war strategies. Currently, there are many techniques to avoid active radar observation, including flying as low as possible under the active radar antenna tilting, active radar is very difficult to detect aircraft capable of stealth where the signal emitted by the radar will be scattered so that it cannot be detected. Another disadvantage of active radar is that it is very vulnerable to hilly contours of the earth. In addition, the position of active radar is very easy to know its position because active radar emits electromagnetic waves continuously, allowing the enemy to know the active radar position of friendly troops.

By seeing the rapid development of stealth aircraft technology and the maneuvering tactics of combat aircraft that always try to avoid radar capture, it is time for Indonesia to use passive radar as an important element of air defense operations. For the world of defense, radar is an eye that can detect where a threat is coming from.

The purpose of writing an article on the operation of passive radar is to illustrate the importance of passive radar early detection tools to complement the Indonesian defense system. The benefit of this paper is to give consideration to leaders in the field of defense in making decisions and gain insight into the world of radar, especially passive radar.

\section{II.RESEARCH METHODS}

The research method used is descriptive qualitative by taking data from literature and literature study. Some of the data is taken from observations and observations to units of TNI radar users. The discussion focuses on the importance of using passive radar in the universal war strategy in the defense of the total people of the Unitary State of the Republic of Indonesia in the face of the times and the growing threats to violations of land, sea and air areas.

The theory used in this discussion is the theory of Defense Policy Implementation Lukman Yudho Prakoso said that public policy in the defense sector can be achieved well if Integrative, Interactive, Transparency, Controling and Accountability (IITCA) factors are respected. ${ }^{3}$

The next theory used is the strategy theory from the war theory and the strategy of Carl Von Clauswitz. strategy is a way to achieve the political goals of the State (ends) that use military power as a means (ways), but this is not a mere military force or political objective, but the use of military power is the ultimate goal of a state political policy. ${ }^{4}$ Military power as a tool or means is the ultimate goal in order to achieve the political goals of a country. The goal to be achieved requires an appropriate way and plan, the method and plan is a strategy which is a description of the existing goals or objectives to be achieved or Ends, the means used to achieve these goals or Ways or and the infrastructure and resources used to achieve goals or Means ${ }^{5}$. In the context of Indonesia's national defense, strategy is an elaboration of the national defense doctrine formulated based on the history of the nation and past, present, and visionary-oriented

\footnotetext{
${ }^{3}$ Lukman Yudho Prakoso (2016), Implementation of Government Agency Performance Accountability System Policy (SAKIP) in the Procurement of Goods and Services, Doctoral Dissertation of Administrative Sciences, University of 17 August 1045 Surabaya.

${ }^{4}$ Clausewitz, Carl von. 1984. On War. (Trans. From Vom Kriege. Princeton University Press. Michael Howard and Peter Paret). New York: Oxford University Press

${ }^{5}$ Lykke, Arthur F, 1997. "Defining Military Strategy" in Military Review No 77 Vol 1.
} 
experiences that are capable of adapting to the development of the strategic e.

\section{RESULTS AND DISCUSSION}

Passive Radar is an electronic device that functions to detect targets / targets by utilizing the electromagnetic wave signal emitted by the target itself and utilizing echo signals from electromagnetic waves emitted from its surroundings. The difference between active radar and passive radar in the way they work is that active radar uses emitted electromagnetic waves to detect targets, whereas passive radar detects targets without emitting electromagnetic wave signals. There are two main methods of passive radar work, namely the Passive Coherent Locater (PCL) method and the Passive Emitter Tracker. (PET). Usually, to facilitate the identification of passive radar civil aircraft, one more method is added, namely Automatic Dependent Surveillance Broadcast (ADSB).

The Ministry of Defense Balitbang in collaboration with PT Lapi ITB carried out research on the making of a Passive Radar prototype that combines several of the above methods into one Passive Radar system which has been tested for its capabilities in November 2020 and has been demonstrated in front of Ministry of Defense officials. The prototype of the $\mathrm{R}$ $\&$ D results is of course still not perfect and there must be improvements for improvement, so it requires the following stages so that it can be used by the TNI, especially the Air Force. The image of the Passive Radar prototype from the Research and Development Research and Development Ministry of Defense can be seen in Figure 2.

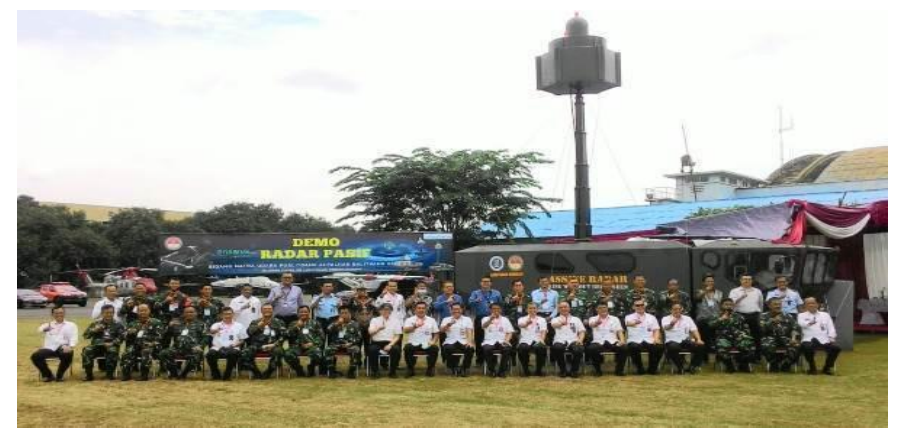

Fig2. Indonesia's Passive Padar

The implementation of the system is detected early by using and operating passive radar for the benefit of national defense, there are several principles that must be followed, namely integrative, interactive, transparency and control . According to Lukman Yudho Prakoso 2016 theory regarding IITCA, that the operation of passive radar in order to strengthen national defense will maximum and effective if they meet these principles. This is related to how to integrate, socialize, how to source the procurement, how to control the operational aspects, and how to calculate the number of passive radar needs required by the state defense to be more efficient and accountable.

It is imperative that today's war is the existence of interoperability between military defense equipment forces in one command. Between one power and another must be connected. This is necessary for a fast and precise decisionmaking process. With the integrative principle among several forces, it will provide a lot of data that can be processed into a command decision. In air defense operations carried out by Kohanudnas, especially the observation of national airspace, all targets from military and civilian detection results have been integrated into the Sector Operation Center (SOC) and the Air Defense Operation Center (ADOC). For passive radar data this should be the case. This will complement the radar target data that goes to ADOC.

According to Lukman Yudho Prakoso 2016 theory, the development of defense forces must adhere to the principle of interactives, namely the principle of reciprocal communication between each unit in the framework of coordination. The TNI K4I system that is used as a communication integration system must be able to carry out reciprocal communication, especially between passive radar target data and $\mathrm{COC}$, where passive radar also functions as a Ground Control Interception (GCI) radar which can carry out limited control of friendly combat aircraft.

In the process of procuring passive radar defense equipment, it must also have the principle of transparency. This is needed in relation to the technical specifications of the passive radar used. The principle of transparency makes it possible to guarantee user rights to the needs of defense equipment in accordance with user requests. This is done so that there are no manipulations related to the technical specifications of the required Passive Radar defense equipment.

In the military organization, the command line is an absolute thing that must be built into a single unit that is effective and efficient in order to give orders to lower units by upper units quickly and precisely. Therefore, in deploying a Passive Radar to detect land, sea and air targets, there must be a principle of strict controlling. Because in the army command system there should be no action without orders from superiors, so everything was completely under control.

In the principle of deploying the Passive Radar defense equipment, the principle of Accoutability is very much needed, because the number of defense equipment that is deployed must be measured so that the number of defense equipment that is deployed must be effective and efficient. That way there is no deployment of defense equipment that is not in accordance with the needs. In areas that are full of violations, the portion of the placement of Passive Radar is certainly more than in areas where there are minimal violations.

In the doctrine of national defense it is said that the essence of universal war is a total war for all Indonesian people by 
mobilizing all national strength and resources to uphold state sovereignty, territorial integrity, and national safety from other nations that threaten or occupy the territory of the Republic of Indonesia. The Universal People's War is populist, universal and territorial. ${ }^{6}$ The strategy of universal war involves all components of the nation, including the main components, reserve components and supporting components. Where the deployment of Passive Radar can be carried out by the main component in areas deemed necessary to detect incoming threats.

In the use of passive radar to support the universal war strategy, the theory used is strategy theory. Carl Phillip Gottfried von Clausewitz defines strategy as: "The employment of the battle as means towards the attainment of the objects of the war. "Strategy is the use of combat as a means of achieving war objectives. Arrangement of ways of fighting to achieve goals. ${ }^{7}$ So strategy is the ability to use ways, means to achieve ends .

The aim of the policy ( ends ) for the operation of Passive Radar in the universal war strategy in Indonesia is in the context of land, sea and air defense which is the responsibility of the TNI. Passive radar technology has the advantage that it does not transmit a signal, it can detect targets with 3 dimensions, that is, it can display azimuth and altitude distance data. Another advantage is that the Passive Radar is more resistant to enemy jamming frequency attacks.

The deployment of Passive Radar in the future is expected to be able to overcome the "blank spots" of national airspace. Where at this time the TNI hanud radar which is spread throughout Indonesia has not been able to maximally cover the entire airspace of the Republic of Indonesia. Penngelaran is also expected to be able to detect targets in land and sea border areas. Areas prone to violations include the Indonesian Archipelago Sea Route (ALKI), where this route is often traversed by foreign ships including aircraft carriers of major countries, namely the United States. This has happened several years ago with the famous "Bawean" incident. At that time, US fighter aircraft maneuvered over Bawean Island which was based on the aircraft carrier. Of course, the aircraft carrier entered the Bawean area through the ALKI route. Besides that, Indonesia's land borders are also vulnerable areas, such as North Kalimantan and West Kalimantan. It is alleged that there are frequent shifts of border stakes which greatly disturb the territory of the Republic of Indonesia.

When it is already in place, it is hoped that this Passive Radar data can be integrated with other detection systems, namely the Active Radar belonging to the Kohanudnas and the Civil Radar belonging to the airports in Indonesia to maximize the ability of the national airspace as a whole. The concept is that the Passive Radar becomes a unit or element under the

\footnotetext{
${ }^{6}$ Prabowo, LTJ (nd) Pokok-pokok Pemikiran Tentang Perang Semesta (Ketiga). PPSPN.

${ }^{7}$ Marsono, TL (2020). Teori Strategi dari berbagai ahli (Pertama). UNHAN PRESS.
}

National Kohanudnas which is connected under the command control under Pangkohanudnas. Integrated not only in data but also includes codic communications.

Currently, Passive radar technology has not been widely used by Indonesia, especially the TNI. Meanwhile in the military world, the developed countries of the Passive Radar have been developed so rapidly, as developed by eastern bloc countries such as Russia, Ukraine and even China. This is to keep pace with the development of aircraft technology in Western countries which continue to develop stealth technology. In the strategy theory, the ways used in implementing the universal war strategy through the operation of the Passive Radar include one of them is carrying out the activity of " Passive Radar Reasearch and Development ."

Currently, the Ministry of Defense of the Republic of Indonesia, in this case Balitbang Kemhan, has carried out research and development of Passive Radar which lasted for 4 years, from 2017 to 2020. This research is the result of collaboration between Balitbnag Kemhan and PT Lapi ITB. The results of these studies have produced a Passive Radar prototype consisting of 1 Master Station and 3 Remote Stations. Where the prototype has the ability to detect targets with 3 methods, namely the Passive Coherent Locater (PCL), Passive Emitter Tracker (PET) and Automatic Dependent Surveillance Broadcast (ADSB). In November 2020, the Passive Radar Prototype was tested and a Passive Radar demonstration was carried out which was witnessed by Kemhan officials, TNI AU officials where the Air Force was a candidate for the alutsista user. The demonstration was also attended by the Indonesian Navy and the Army, especially from Arhanud.

In meeting its needs for equipment related to detection devices, the Ministry of Defense has also imported 2 units of the Vera NG brand of defense equipment from the state-made country of Czechoslovakia, which are planned to be handed over by the Indonesian Air Force and operated in Kohanudnas. The deployment plan will be implemented in 2020 in Ranai, Natuna and Saumlaki, Southeast Maluku islands. Both Radar are currently in the installation process.

There are two sides to the means ( means) used in the operation and deployment of the Passive Radar, namely the regulatory side and the deployment facility. From the regulatory side, it is necessary to include the organizational position of the Passive Radar and the operating procedures at the Kohanudnas Protap to provide a legal umbrella for the operation of the Passive Radar. The second is from the deployment system, it is necessary to have transportation facilities for the placement of Passive Radar as needed. For transportation facilities, the Indonesian Air Force uses C-130 Hercules aircraft.

\section{CONCLUSIONS AND RECOMMENDATIONS}

In the application of the universal war strategy, it is necessary to have a sensing system and an early detection tool against 
the arrival of threats both coming from land, sea and air border areas. Operation of the Passive Radar is an alternative for the TNI to use it as an early detection tool, where currently the TNI only relies on Active Radar to observe airspace. The task is carried out by the Kohanudnas.

The reason for the need for Passive Radar is to detect targets that cannot be detected by Active Radar, so that it can be used as a " gap filler for Radar, " where there are still many areas that are not detected by Active Radar. Apart from that, another advantage with the operation of this Active Radar is that it can detect stealth aircraft targets whose material is made of materials that absorb electromagnetic waves. However, from the signal emitted from the navigation device and the aircraft's communication the target of the aircraft can be detected.

To maximize the ability of the universal war strategy properly throughout the territory of the Republic of Indonesia, all of the Indonesian airspace must not have any gaps for territorial violations without detection. So that the operation of the Passive Radar must be integrated with the TNI Hanud Radar and the airport civil radar which can be integrated into the Kohanudnas Control Command Center. This is a matter for the leadership of the TNI to take decisions on actions in order to deal with violations of Indonesian territory by foreign parties.

To maximize the universal war strategy with the operation of this Passive Radar, it is advisable to use domestic defense equipment, where the Ministry of Defense Balitbang has carried out Radar Passive R\&D which has produced a prototype that can be further developed for " mass production
" by the defense industry in Indonesia. Because one of the characteristics of a strong country in the military is that the country can meet its needs for defense equipment with domestic production.

\section{BIBLIOGRAPHY}

Journal

[1] Indrawan, Jerry \&Widiyanto, Bayu. "Korupsi sebagai Bagian dari Perang Proxy: Upaya untuk Memberantas Bahaya Korupsi di Indonesia", Jurnal Pertahanan \& Bela Negara, Vol. 7, No. 1, 2017, hlm. 32-33

Book

[2] Buku Putih Pertahanan 2015, hlm 28-29

[3] Prosedur Tetap Operasi Pertahanan Udara, Kep Pangkohanudnas No: KEP/79/xii/2017, tgl 14 Desember 2017.

[4] Darmawan, Cecep. "Pendidikan Bela Negara dalam Konteks Keamanan Nasional", dalam Muradi (ed.), Penataan Kebijakan Keamanan Nasional, (Bandung: Dian Cipta, 2013), hlm. 115.

[5] Marsono, T. L. (2020). Teori Strategi dari berbagai ahli (Pertama). UNHAN PRESS.

[6] Prabowo, L. T. J. (n.d.). Pokok-pokok pemikiran tentang perang semesta (ketiga). PPSN.

[7] Moleong, Lexy J. Metode Penelitian Kualitatif (edisi revisi), (Bandung: PT. Remaja Rosda Karya, 2012), hlm. 6.

Website

[8] Lukman, Agus. "Begini Kurikulum Bela Negara Versi Kemenhan untuk Siswa PAUD Hingga Perguruan Tinggi", dalam http://kbr.id/nasional/01-

2017/begini_kurikulum_bela_negara_versi_kemenhan_untuk_sis wa_paud_hingga_perguruan_tinggi/88285.html, 21 Januari 2017, diakses pada 24 Februari 2018.Ginter, P. M., Duncan, W. J., \& Swayne, L. E. (2018). The strategic management of health care organizations. John Wiley \& Sons. 